Journal of Agrometeorology 23 (4) : 402-408 (December 2021) : https://doi.org/10.54386/jam.v23i4.144

\title{
Detection of annual and seasonal temperature variability and change using non-para- metric test- A case study of Bundelkhand region of central India
}

\author{
SUCHIT K. RAI ${ }^{*}$, SUNIL KUMAR and MANOJ CHAUDHARY \\ ICAR-Indian Grassland and Fodder Research Institute, Jhansi, India \\ *Corresponding author email : Suchitrai67@yahoo.co.in
}

\begin{abstract}
Consequences of global warming and climate change are major threat to humans and their socio-economic activities. Agriculture of Bundelkhand region is supposed to be more vulnerable due to emerging scenario of climate change and poor socio-economic status of farming community. Many studies carried out elsewhere have shown evidence of regional temperature variability along with global climate changes. This study focuses on the temporal variability and trend in annual and seasonal temperature (1901-2015) at six locations of Bundelkhand region. The results of the analysis reveal that the annual maximum $\left(\mathrm{T}_{\mathrm{Max}}\right)$ and minimum $\left(\mathrm{T}_{\mathrm{Min}}\right)$ temperature has significantly increasing trend in all the locations in the range of 0.5 to $2.0^{\circ} \mathrm{C} 100$ year $^{-1}$ and 0.5 to $1.1^{\circ} \mathrm{C} 100$ year $^{-1}$, respectively. Seasonal analysis revealed warming trend in both $\mathrm{T}_{\text {Max }}(0.6-$ $2.6^{\circ} \mathrm{C} 100$ year $\left.^{-1}\right)$ and $\mathrm{T}_{\text {Min }}\left(0.9\right.$ to $2.3^{\circ} \mathrm{C} 100$ year $\left.^{-1}\right)$ during post-monsoon and winter season in all the locations. Majority of the locations showed cooling trend $\left(0.3-1.0^{\circ} \mathrm{C} 100\right.$ year $\left.^{-1}\right)$, in the mean maximum and minimum temperature during monsoon season except at two locations i.e Jhansi and Banda. However, a significant positive trends $\left(2.9^{\circ} \mathrm{C}\right)$ in the $\mathrm{T}_{\text {Min }}$ was found for the period of hundred years at Banda district during monsoon season.
\end{abstract}

Key words: Climate change, climate variability, mann-kendall test, temperature, trends

Climatic change over the last and current century has been a subject of great interest. The threat of climate change is pondering this problem to the scientific community as it may lead towards a major impact on natural and social system at local, regional and national scales. The global temperatures have increased by 0.5 $0.6^{\circ} \mathrm{C}$ and it has been estimated that it would increase by $0.3-0.7^{\circ} \mathrm{C}$ by 2035 (Jaswal et al. 2015). This is attributed to changes in radiative forcing (Thomas et al. 2012) due to changes in landscape or modification of vegetation cover, surface moisture variability and anthropogenic activity. However, in a recent study, England et al. (2014) reported that mean global air temperature remained constant since 2001, despite continuous increased concentration of green house gases into the atmosphere. From studies it has been confirmed that the most important aspects of climatic change studies is to determine variability and trends in rainfall and temperature. Many workers have reported significant changes in temperature and precipitation all over the world for which some recent example can be cited from United States (Vose et al., 2017), India (Prasad et al., 2017) and Brazil (Rosso et al.,2015).

For Indian region (south Asia), the IPCC has projected $0.5-1.2{ }^{\circ} \mathrm{C}$ rise in temperature by $2020,0.88$ $-3.16^{\circ} \mathrm{C}$ by 2050 and $1.56-5.44{ }^{\circ} \mathrm{C}$ by 2080 (IPCC 2007). The trend and magnitude (the rate of $0.57^{\circ} \mathrm{C} / 100$ years) of warming over India during the past century is close to the global trend and magnitude(Dash et al.2007). Atmospheric surface temperature in India has increased in the last century by about $1^{\circ} \mathrm{C}$ and $1.1^{\circ} \mathrm{C}$ during winter and post-monsoon months, respectively (Jain and Kumar,2012). Season based study showed that eight sites in Central Northeast India, the maximum temperature has shown rising trend of $0.008^{\circ} \mathrm{C}$ year ${ }^{-1}$ during monsoon season; $0.014^{\circ} \mathrm{C}$ year $^{-1}$ during post-monsoon season and $0.008^{\circ} \mathrm{C}$ year $^{-1}$ in the annual temperature during the period 1914-2003, while minimum temperature showed significant rising trend of $0.012^{\circ} \mathrm{C}$ year ${ }^{-1}$ during postmonsoon season and significant falling trend of $0.002^{\circ} \mathrm{C}$ year $^{-1}$ during monsoon season (Subash et al. 2010). Temporal trend of long-term climatic parameters may be studied using non-parametric statistical methods (Mann, 1945; Kendall, 1955 ).

Climate change and variability of temperature and rainfall may negatively affect water resources for 
agricultural production of agrarian country like India. Wheat production will be reduced by 5 million tones, if there is a rise of temperature by $1^{\circ} \mathrm{C}$ throughout the growing period (Aggarwal,2007). He suggested that by employing simple strategies like change in planting dates and varieties could help in reducing adverse effect of climate change to some extent. In Bundelkhand region, temperature plays important role in agriculture activities like cropping pattern which ultimately influence productivity, local livelihood activities and economic enterprises (Rai et al. 2017). In view of the above facts, this study was undertaken to detect the temporal trends in annual and seasonal time series of temperature of Bundelkhand region of Central India, which will be helpful for agricultural planning and in devising the local specific climate change mitigation and adaptation strategies.

\section{MATERIALS AND METHODS}

\section{Description of the study area and long term climatic data}

The study was conducted at six locations viz. Jhansi $\left(25.4{ }^{\circ} \mathrm{N}, 78.6{ }^{\circ} \mathrm{E}, 285 \mathrm{~m}\right.$ amsl), Banda $\left(25.5^{\circ} \mathrm{N}\right.$, $80.3^{\circ} \mathrm{E}, 123 \mathrm{~m}$ amsl), Mahoba $\left(25.4^{\circ} \mathrm{N}, 79.8^{\circ} \mathrm{E}, 214 \mathrm{~m}\right.$ amsl), Lalitpur $\left(24.6^{\circ} \mathrm{N}, 78.5^{\circ} \mathrm{E}, 428 \mathrm{~m}\right.$ amsl), Jaluan $\left(26.1^{\circ} \mathrm{N}, 79.5^{\circ} \mathrm{E}, 164 \mathrm{~m}\right.$ amsl) and Hamirpur $\left(25.8^{\circ} \mathrm{N}, 80.0\right.$ ${ }^{\circ} \mathrm{E} 80 \mathrm{~m}$ amsl) of Bundelkhand region of central India. All the locations are characterized by low and erratic rainfall occurring from mid June to last week of September and also experience regular drought (early, mid and late season ).The major soils are locally known as Rakar (17.6\%) and Parwa (38.5\%) in red soil group and Kabar $(31.4 \%)$ and $\operatorname{Mar}(12.4 \%)$ in black soil group and are inherently deficient in $\mathrm{N}, \mathrm{P}$ and $\mathrm{K}$. Main enterprises of the region are mixed crop livestock production systems with major crops being sorghum, maize, green gram, groundnut, pigeon pea and rice during rainy season. In this region, major rabi crops grown are wheat, peas, lentil, barley and chickpea. The weekly temperature data of these locations for the period of 1901-2015 have been obtained from the sources viz. India Meteorological Department (IMD), Pune, India, Agro-meteorological Observatory, CR, Farm, ICAR-IGFRI, Jhansi. These data were converted into annual and seasonal series for further analysis.

\section{Data analysis}

Annual and seasonal rainfall series have been worked out for testing its variability as well as normality. Statistical parameters (mean, standard deviation (SD), etc. ) were computed for temperature series for annual (January-December) and season wise viz., pre monsoon (March-May), monsoon(June-September), post monsoon (October-November) and winter(December- February) season. Trend analysis was carried out using nonparametric method (Jain and Kumar, 2012; Mann,1975; Kendall,1945 ) and least square techniques. Also Sen's slope technique (Sen,1968) was used to determine the magnitude of the trend line.

\section{RESULTS AND DISCUSSION}

\section{Mean annual and seasonal variability in maximum temperature}

The mean annual $\mathrm{T}_{\text {Max }}$ of this region varied from 31.8 to $32.6{ }^{\circ} \mathrm{C}$ being highest at Jhansi and lowest at Lalitpur with $\mathrm{CV}$ from $1.3 \%$ to $2.5 \%$. At Jhansi, the range of maximum temperature varied from $34.2{ }^{\circ} \mathrm{C}$ in the year 2006 to 30.0 in the year 1970 with mean of $32.6{ }^{\circ} \mathrm{C} \pm 0.8{ }^{\circ} \mathrm{C}$ and $\mathrm{CV}$ was found to be $2.5 \%$ (Table 1). Similarly, the variation in mean annual temperature were found to be 30.1 to 34.2 for the rest of the locations. It is clear from Table 1 in pre and post monsoon season, maximum temperature was highest i.e.38.9 $\pm 1.0{ }^{\circ} \mathrm{C}$ and $31.6 \pm 1.0{ }^{\circ} \mathrm{C}$, respectively at Jhansi as compared to rest of the locations. During monsoon season, mean $\mathrm{T}_{\text {Max }}$ was highest $\left(34.8{ }^{\circ} \mathrm{C}\right)$ at Jalaun and lowest at Jhansi $\left(33.1^{\circ} \mathrm{C}\right)$. The variation in maximum temperature during monsoon season were found to be 30.9-36.7 in these locations. Similarly, mean maximum temperature during winter season varied in the range 24.2 (Jalaun) to $25.0^{\circ} \mathrm{C}$ (Banda) and variation in maximum temperature were found to be 21.6-26.4, 22.9-26.8, 22.9-26.4, 22.8-26.5. 18.0-26.8 in these region (Table1).

\section{Annual and seasonal trends in maximum temperature}

The long term annual and seasonal temperature data were subjected to 5 point moving average and then regression equation was worked out slope 'SL' and tested for the significant trends. The mean annual and seasonal trends in maximum temperature are presented in Table 1. Mean annual $\mathrm{T}_{\mathrm{Max}}$ at Jhansi shows an increasing trend 
Table 1: Statistical parameters of annual and seasonal maximum temperature

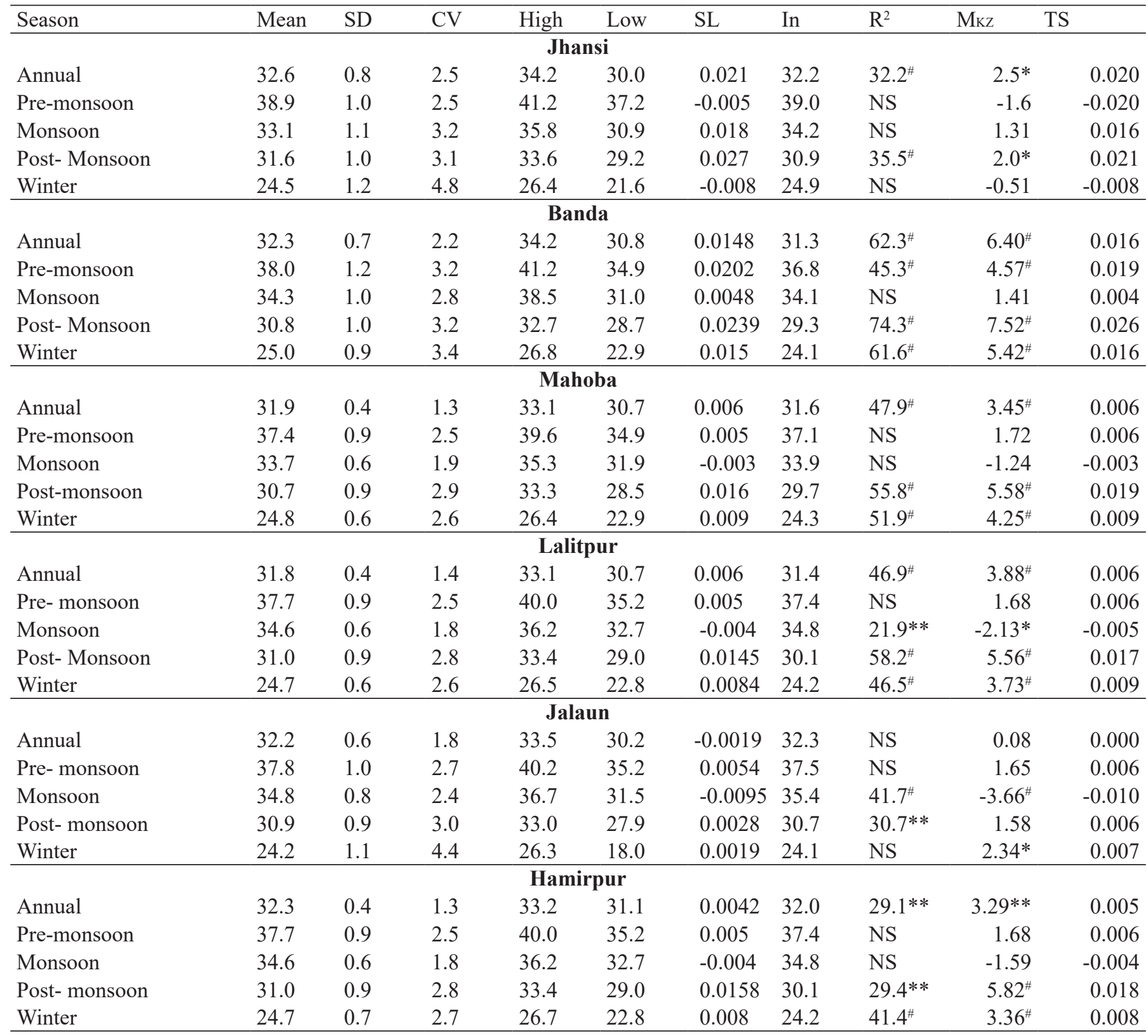

*** and ${ }^{*}$, Significant at 5, 1 and $0.1 \%$ level, NS: Non significant, In: Intercept

with a rate of $0.021^{\circ} \mathrm{C}$ year ${ }^{-1}$ and statistically $\left(\mathrm{R}^{2}=32.2 \%\right)$ significant $(\mathrm{P}<0.05)$. This trend corresponds to an increase of $0.99^{\circ} \mathrm{C}$ and $0.61^{\circ} \mathrm{C}$ over the total period analyzed (19692015) and over the normal temperature, respectively. The Mann-Kendall test $\left(\mathrm{M}_{\mathrm{KZ}}=2.5\right)$ confirmed that positive trend observed is statistically significant at $\mathrm{P}<0.05$ level. The trend tests also identified significant increasing trends in annual $\mathrm{T}_{\text {Max }}$ at Banda, Mahoba, Lalitpur, and Hamirpur with the magnitude of $0.016{ }^{\circ} \mathrm{C}$ year ${ }^{-1}, 0.006^{\circ} \mathrm{C}$ year ${ }^{-1}$, $0.006{ }^{\circ} \mathrm{C}$ year ${ }^{-1}$ and $0.005^{\circ} \mathrm{C}$ year ${ }^{-1}$, respectively. Overall the mean annual maximum temperature had increased by
0.5 to $1.6{ }^{\circ} \mathrm{C}$ over the period of 100 years. This increase in temperature in this region might be attributed to the green house gases emission, especially $\mathrm{CO}_{2}$, from the different motor vehicles used in the city. The factories around the city as well the increase in human activities and the dearth of green areas and parks in the city also contribute to the warming of the city. This warming trend will be expected to adversely affect almost all crops of the regions in terms of productivity and consequently the economics of the Bundelkhand region. 
Table 2 : Least square slope, intercept and statistical test of annual and seasonal maximum temperature at Jhansi

\begin{tabular}{lllllllllll}
\hline Period & \multicolumn{9}{c}{$1969-2015$} & \multicolumn{3}{c}{$1985-2015$} \\
Fortnight & Sl & In & $\mathrm{R}^{2}(\%)$ & Mkz & TS & Sl & In & R$^{2}(\%)$ & MKZ & TS \\
\hline Jan-I & -0.075 & 23.9 & 41.4 & $-2.47^{*}$ & -0.072 & -0.13 & 23.8 & 57.7 & $-3.09^{* *}$ & -0.156 \\
Jan-II & -0.008 & 23.4 & NS & -0.85 & -0.017 & -0.10 & 25.0 & 50.2 & $-3.03^{* *}$ & -0.129 \\
Feb-I & 0.015 & 24.2 & NS & 0.76 & 0.020 & -0.11 & 26.9 & 55.5 & $-2.70^{* *}$ & -0.127 \\
Feb-II & -0.031 & 28.1 & 25.7 & -1.38 & -0.037 & -0.07 & 28.4 & 41.35 & $-1.85^{* *}$ & -0.075 \\
Mar-I & -0.023 & 32.8 & NS & -1.52 & -0.043 & -0.11 & 33.9 & 73.59 & $-2.86^{* *}$ & -0.138 \\
Mar-II & 0.0039 & 35.3 & NS & -1.02 & -0.026 & 0.023 & 34.9 & 12.9 & -0.05 & -0.117 \\
\hline
\end{tabular}

I and II showed first and second fortnight of the month; * and **, Significant at 5 and $1 \%$ level, NS: Non significant, In: Intercept

The least square method did not reveal significant increasing trend in all the locations during pre monsoon season except Banda district, where it is increasing with a rate of $0.0202{ }^{\circ} \mathrm{C}$ which corresponds to an increase of $2.02{ }^{\circ} \mathrm{C}$ over the period of 100 years (Table 1). In monsoon season, both statistics revealed that maximum temperature showed significantly declining trend with a rate of 0.004 and $0.0095{ }^{\circ} \mathrm{C}_{\text {year }}{ }^{-1}$ at Lalitpur and Jalaun, respectively. In post-monsoon season, all the locations showed significantly $(\mathrm{P}<0.05)$ increasing trend with a magnitude ranging from 0.014 to $0.03^{\circ} \mathrm{C}$ year $^{-1}$, except Jalaun. Overall the maximum increase of $2.7^{\circ} \mathrm{C}$ was found at Jhansi followed by Banda $\left(2.4^{\circ} \mathrm{C}\right)$, Mahoba $\left(1.6^{\circ} \mathrm{C}\right)$, Lalitpur $\left(1.45^{\circ} \mathrm{C}\right)$ and Hamirpur $\left(1.6^{\circ} \mathrm{C}\right)$ over the period of 100 years. In winter season a significant increasing trend in maximum temperature was noted with an overall increase of 0.8 to $1.5^{\circ} \mathrm{C}$ over a period of 100 years in Bundelkhand region of central India (Table 1). The results are in conformity with the report of Intergovernmental Panel on Climate Change (IPCC,2007) which predicted that global temperature would rise by 1.4 to $5.8^{\circ} \mathrm{C}$ by the year 2010 .

Since, there was non-significant decreasing trend during winter season at Jhansi, the months of winter season (December to March) was divided into fortnightly series and trend was examined to understand the likely impact on wheat crop to have maximum productivity. However the first fortnight of January (Jan-I) showed a significant $(\mathrm{P}<0.01)$ decreasing trend with a rate of $0.075^{\circ} \mathrm{C}$ year $^{-1}$ and the temperature during this period has decreased by $3.52{ }^{\circ} \mathrm{C}$ over the period of $1969-2015$ (Table 2). The Mann-Kendall rank tests also confirmed the decreasing trend in maximum temperature. However, current climate (1985-2015) data reinforced that each fortnight for the month of December to March showed significant $(\mathrm{P}<0.01)$ decreasing trend with a rate ranging from $\left(0.023\right.$ to $0.13{ }^{\circ} \mathrm{C}$ year $\left.{ }^{-1}\right)$. This could resulted into a maximum $\left(3.9^{\circ} \mathrm{C}\right)$ and minimum $\left(0.69{ }^{\circ} \mathrm{C}\right)$ decrease of temperature, respectively in the total analyzed period (1985-2015).

\section{Annual and seasonal variability in minimum temperature}

Mean annual and seasonal minimum temperature $\left(\mathrm{T}_{\text {Min }}\right)$ along with statistical parameters are presented in Table 3. Annual mean minimum temperature in this region varied from $18.0 \pm 1$ at Jhansi to $18.9 \pm \pm^{\circ} \mathrm{C}$ at Lalitpur with a CV of 2.2 to $5.8 \%$. Similarly, among the locations, mean minimum temperature varied from 20.9 \pm 0.9 to $22.5 \pm 1.6{ }^{\circ} \mathrm{C}$ in pre-monsoon, $23.9 \pm 0.6$ to 25.6 $\pm 0.9^{\circ} \mathrm{C}$ before monsoon, $15.4 \pm 0.9$ to $16.5 \pm 1.0{ }^{\circ} \mathrm{C}$ in post-monsoon and $8.1 \pm 1.3$ to $10.7 \pm 0.7{ }^{\circ} \mathrm{C}$ in winter season. From Table 3, it is noted that the higher degree of inter annual variability appeared in mean $\mathrm{T}_{\text {Min }}$ during post-monsoon season(6.8 to $15.7 \%$ ) followed by winter season(5.6-11.4\%) in this region as compared to premonsoon (4.2-7.3\%) and monsoon season (2.3-5.1\%). At Jhansi mean annual temperature showed a significant cooling trend of $0.020^{\circ} \mathrm{C}_{\text {year }}{ }^{-1}$ for the period $1969-2015$. The minimum temperature decreased at Jhansi with a rate of $0.02{ }^{\circ} \mathrm{C}$ year-1 (Table 3). This cooling was mainly contributed due to decline of temperature in winter ( 2.9 oC 100 year $\left.^{-1}\right)$, pre-monsoon $\left(5.4100^{\circ} \mathrm{C}_{\text {year }}{ }^{-1}\right)$ and postmonsoon seasons $\left(3.2^{\circ} \mathrm{C} 100\right.$ year $\left.^{-1}\right)$.

In annual $\mathrm{T}_{\text {Min }}$ temperatures, Mann Kendall rank statistics exhibited significant warming trend at Banda, Mahoba, Lalitpur, Jaluan and Hamirpur in the range between 0.005 to $0.011^{\circ} \mathrm{C}$ year ${ }^{-1}$ being highest at Banda and lowest at Jalaun (Table 3). The trends corresponds to 
Table 3 Statistical parameters of annual and seasonal minimum temperature

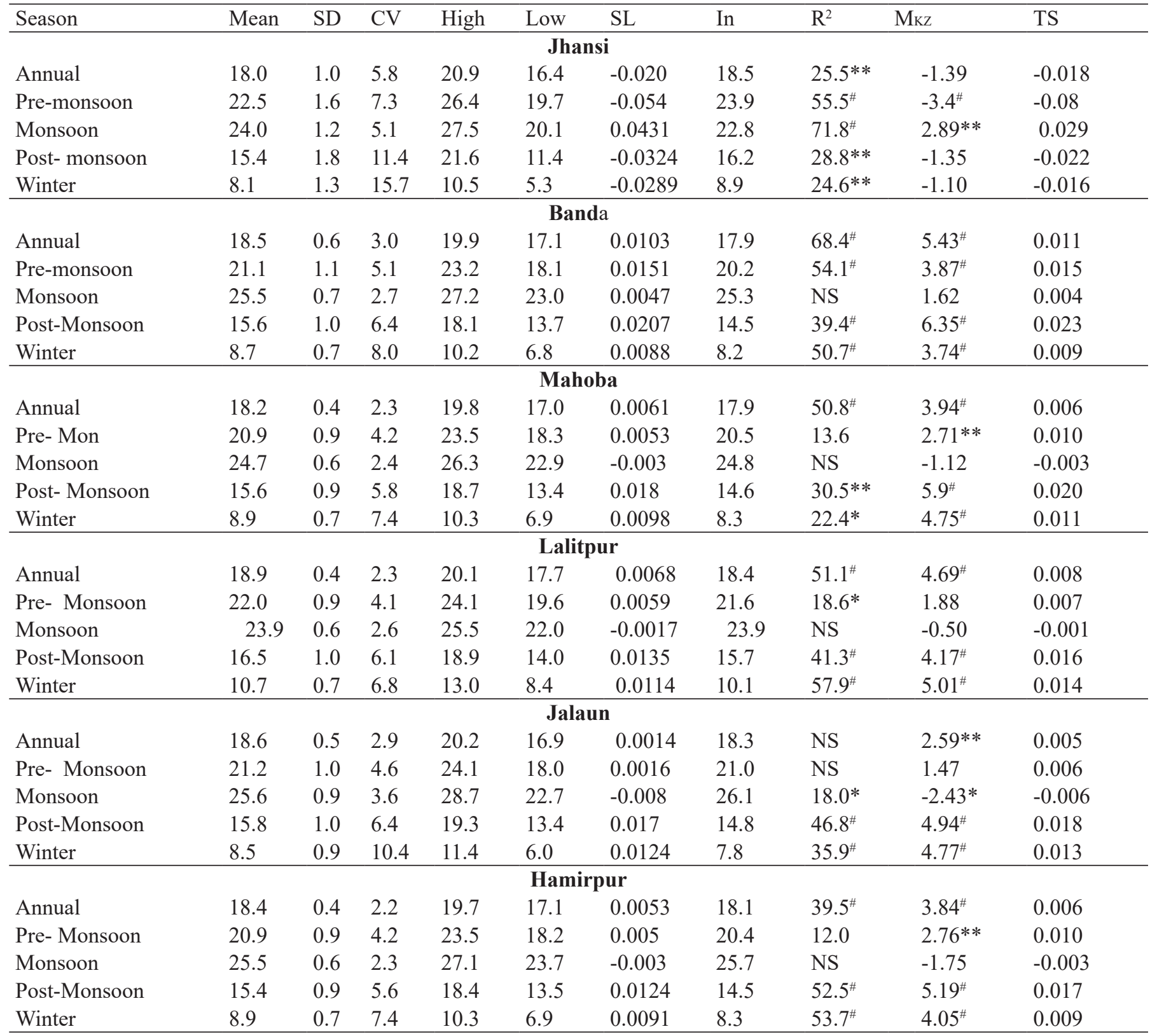

***,and ${ }^{\#}$, Significant at 5, 1 and $0.1 \%$ level, NS: Non significant, In: Intercept

an increase of $1.10,0.60,0.80,0.50$ and $0.60^{\circ} \mathrm{C}$ over the period of 100 years for the respective locations. Theil's Sen slope are also close to the least square slope at few of locations. However, at Jhansi mean annual temperature showed a significant cooling trend of $0.020^{\circ} \mathrm{C}$ year ${ }^{-1}$ during the period 1969-2015. In pre-monsoon season, three locations viz., Banda $\left(0.015{ }^{\circ} \mathrm{C}\right.$ year $\left.{ }^{-1}\right)$, Mahoba $\left(0.010{ }^{\circ} \mathrm{C}\right.$ year $\left.{ }^{-1}\right)$ and Hamirpur $\left(0.010{ }^{\circ} \mathrm{C}\right.$ year $\left.{ }^{-1}\right)$ exhibited significant $\left(\mathrm{M}_{\mathrm{KZ}}\right.$ and $\mathrm{R}^{2}$ is $\left.\mathrm{P}<0.05\right)$ warming trend in mean $\mathrm{T}_{\text {Min }}$. The trends corresponds to increase in minimum temperature by $1.5,1.0$ and $1.0^{\circ} \mathrm{C} 100$ year $^{-1}$ for the respective locations. However, a negative trend with a rate of $0.054^{\circ} \mathrm{C}$ year ${ }^{-1}$ at Jhansi was noticed during premonsoon season and it has decreased by $2.53^{\circ} \mathrm{C}$ and $1.04^{\circ} \mathrm{C}$ over the period of 47 years and from the its long period average $\left(22.5^{\circ} \mathrm{C}\right)$, respectively and Mann-Kendall statistics $(3.39 ; \mathrm{P}<0.01)$ also confirmed the presence of negative trend (Table 3 ). In monsoon season, Jhansi and Jalaun showed significant $(\mathrm{P}<0.05)$ warming $\left(0.043{ }^{\circ} \mathrm{C}\right.$ year $\left.{ }^{-1}\right)$ and cooling $\left(0.008{ }^{\circ} \mathrm{C}\right.$ year $\left.{ }^{-1}\right)$ trend, respectively (Table 3). During post-monsoon and winter season, majority of locations viz., Banda, Mahoba, Lalitpur, 
Table 4 Least square slope, intercept and statistical test of annual and seasonal minimum temperature in Jhansi

\begin{tabular}{|c|c|c|c|c|c|c|c|c|c|c|}
\hline Period & & & $9-2015$ & & & & & $35-2015$ & & \\
\hline Fortnight & $\mathrm{S} 1$ & In & $\mathrm{R}^{2}(\%)$ & $\mathrm{M}_{\mathrm{KZ}}$ & $\mathrm{TS}$ & $\mathrm{S} 1$ & In & $\mathrm{R}^{2}(\%)$ & $\mathrm{M}_{\mathrm{Kz}}$ & TS \\
\hline Dec-II & -0.035 & 7.8 & 38.6 & -1.06 & -0.019 & -0.062 & 7.7 & 37.4 & -1.70 & -0.076 \\
\hline Jan -II & -0.034 & 8.1 & 29.0 & $-2.82 * *$ & -0.039 & -0.111 & 9 & 65.7 & $-3.40^{\#}$ & -0.085 \\
\hline Feb-I & 0.004 & 9.1 & NS & 0.54 & 0.014 & -0.132 & 11.8 & 43.8 & -1.51 & -0.086 \\
\hline Feb-II & -0.052 & 12.6 & 38.2 & $-2.18 *$ & -0.060 & -0.111 & 12.9 & 48.7 & $-2.84 * *$ & -0.112 \\
\hline Mar-II & -0.085 & 19.0 & 55.9 & $-3.49^{\#}$ & -0.090 & -0.16 & 19 & 57.8 & $-3.11 * *$ & -0.144 \\
\hline Apr-I & -0.105 & 22.1 & 58.0 & $-3.57^{\#}$ & -0.105 & -0.16 & 21.4 & 40.1 & $-2.92 * *$ & -0.166 \\
\hline Apr-II & -0.086 & 25.1 & 22.2 & $-3.93^{\#}$ & -0.105 & -0.15 & 25.9 & 65.3 & $-3.91^{\#}$ & -0.169 \\
\hline
\end{tabular}

*,**, and *, Significant at 5, 1 and 0.1\% level, NS: Non significant, In: Intercept; I and II showed first and second fortnight of the month;

Jalaun, and Hamirpur showed positive trend in mean $\mathrm{T}_{\text {Min }}$ with a magnitude ranging between 0.009 to $0.023^{\circ} \mathrm{C}$ year ${ }^{1}$ (Table 3). However, during both the season minimum temperature has significant decreasing trend at Jhansi.

The months of winter season were divided into fortnight period at Jhansi and trend was computed in order to examine the period which was contributing more in cooling. Table 4 reports that each fortnight during December to April showed cooling trend and the rate of decline ranged between 0.035 (Dec-II) to $0.105{ }^{\circ} \mathrm{C}$ year ${ }^{-1}$ (Apr-I) during the period 1969-2015. Theils slope indicated that the trends declining with a higher rate as compared to long term data (1969-2015). It is interesting to note that maximum decrease in minimum temperature during Apr-I (4.95oC/ 47 Years) followed by Apr-II (4.04 oC/47 Years). In the current thirty years (1985-2015), minimum temperature has recorded a significant decreasing trend during Dec-II to Apr-II with higher magnitude as compared to 1969-2015 and the rate of magnitude ranging between 0.076 to $0.185^{\circ} \mathrm{C}$ year- ${ }^{1}$. The trends corresponds to decrease of temperature by $2.28{ }^{\circ} \mathrm{C} / 30$ years and 5.5 ${ }^{\circ} \mathrm{C} / 30$ years during into Dec-II to Apr-II. The implication of this changes in temperature suggests that increase in temperature will reduce the crop duration and wheat yield will decline (Pramod et al. 2017). Therefore, in majority of locations short duration wheat varieties (HI 1500, HI 1531 and HW 2004 ) will be more suitable if it would be sown in the first fortnight of November to avoid adverse effect of increase in temperature during winter season. However, at Jhansi, long duration wheat varieties such as MPO-1215, HI 8498, GW 322 would be performed better by avoiding early flowering.

\section{CONCLUSIONS}

Mean annual $\mathrm{T}_{\text {Max }}$ and $\mathrm{T}_{\text {Min }}$ of this region varied from $31.8 \pm 1.0$ to $32.6+0.8^{\circ} \mathrm{C}$ and $18.0 \pm 1$ to $18.9 \pm 0.4$ ${ }^{\circ} \mathrm{C}$, respectively in Bundelkhand region of central India. Trend analysis indicated that Mean annual maximum and minimum temperature had significant increasing trend in the range of 0.005 to $0.020{ }^{\circ} \mathrm{C}$ year ${ }^{-1}$ in majority of the locations. This corresponds to an increase of warming to the magnitude between 0.50 to $2.0^{\circ} \mathrm{C}$ over the period of 100 years. Magnitude of the increase in annual mean $\mathrm{T}_{\text {Max }}$ was more prominent than $\mathrm{T}_{\text {Min }}$, which is reflected in the overall increase in daily temperature range. Seasonal analysis revealed warming trend in both $\mathrm{T}_{\text {Max }}(0.6-2.6$ ${ }^{\circ} \mathrm{C}$ ) and $\mathrm{T}_{\text {Min }}\left(0.9\right.$ to $\left.2.3{ }^{\circ} \mathrm{C}\right)$ during pre monsoon, post monsoon and winter season over the period of hundred years. However, during monsoon season, majority of the locations showed cooling trend $\left(0.3-1.0^{\circ} \mathrm{C}\right)$ in mean maximum and minimum temperature except two locations i.e., Jhansi and Banda over the period of hundred years. Increasing pattern of both maximum and minimum temperature in Bundelkhand region particularly during post-monsoon and winter season may affect the vegetable and fruit production.

Conflict of Interest Statement: The author(s) declare(s) that there is no conflict of interest.

Disclaimer: The contents, opinions, and views expressed 
in the research article published in the Journal of Agrometeorology are the views of the authors and do not necessarily reflect the views of the organizations they belong to.

Publisher's Note: The periodical remains neutral with regard to jurisdictional claims in published maps and institutional affiliations

\section{REFERENCES}

Aggarwal, P.K. (2007). Climate change: implications for Indian agriculture. Hydrol. Rev., 22: 3746, Roorkee: Indian National Committee on Hydrology.

Dash, S.K., Jenamani, R.K., Kalsi, S.R. and Panda, S.K. (2007). Some evidence of climate change in twentieth century India. Clim. Chang., 85: 299321

England, M.H., McGregor, S., Spence, P., Meehl, G.A., Timmermann, A., Cai, W., Gupta, A.S., McPhaden, M.J., Purich, A. and Santoso, A. ( 2014).Recent intensification of wind-driven circulation in the Pacific and the ongoing warming hiatus. Nat. clim. Chang., 4(3):.222227.

IPCC (2007). Summary for policy makers. In Climate Change 2007: The Physical Science Basis (Eds. Solomon, S. D. et al.), Cambridge University Press, Cambridge, UK, 2007.

Jain, S.K. and Kumar, V. (2012).Trend analysis of rainfall and temperature data for India. Curr. Sci., 102 (1):37-49

Jaswal, A.K., Rao, P.C.S and Singh, V. (2015).Climatology and trends of summer high temperature days in India during 1969-2013. J. Earth Sys. Sci., 124: 1-15.

Kendall, M.G. (1975). Rank Correlation Methods, $4^{\text {th }}$ edition. Charles Griffin, London, U. K.

Mann, H.B. (1945). Nonparametric tests against trend. Econometrica, 13: 245-259.
Pramod, V.P., Rao, B.B., Ramakrishna, S.S.V.S., Singh, M.M., Patel, N.R., Sandeep, V.M., Rao, V.U.M., Chowdhary, P.S., Rao, and V.N., Kumar, P.V. (2017). Impact of projected climate on wheat yield in India and its adaptation strategies. $J$. Agrometeorol., 19(3):207-216.

Prasad , R., Patil, J. and Sharma A. (2017). Trends in temperature and rainfall extrems during recent years at different stations of Himachal Pradesh. J. Agrometeorol., 19(1):51-55

Rai, S. K., Kumar, S., Palsaniya, D. R., Pandey, S. and Chaudhary, M. (2017) Variability and long-term trend in pan evaporation in semi-arid region of Bundelkhand region. J. Agrometeorol,, 19(1):5155.

Rosso, F.V., Nathalie, T., Boiaski1, Simone, E.T., Ferraz1, Candida, F.D and Jonatan, D.T. (2015).Trends and Decadal Variability in Air Temperature over Southern Brazil.Am. J. Environ. Eng., 5(1A):8595 DOI: $10.5923 /$ s.ajee. 201501.12

Sen, P,K. (1968). Estimates of the regression coefficient based on Kendall's tau. J. Am. Stat . Assoc. 63: 1379-1389

Subash, N., Sikka, A.K. and Mohan, H.R. (2011). An investigation into observational characteristics of rainfall and temperature in Central Northeast India - a historical perspective 1889-2008. Theor. Appl. Climatol., 103(3):305-319.

Thomas, P.C., Stott, P.A., and Stephanie, H. (2012). Explaining extreme events of 2011 from a climate perspective. Bulletin Ame. Meteorol. Soc., 93: 1041-1067.

Vose, R., Easterling, D.R., Kunkel, K., \& Wehner, M. (2017). Temperature changes in the United States. In: ( Eds. Wuebbles, D.J., D.W. Fahey, K.A. Hibbard, D.J. Dokken, B.C. Stewart, and T.K. Maycock). Climate Science Special Report: A Sustained Assessment Activity of the U.S. Global Change Research Program Pp.267-300, U.S. Global Change Research Program, Washington, DC, USA. 267-300. 